\title{
DEVELOPMENT OF NEW VALUABLE INTROGRESSION LINES FROM THE INTERSPECIFIC CROSS IN EGGPLANT (SOLANUM MELONGENA L.)
}

\author{
BOYACI, H. F. \\ Bati Akdeniz Agricultural Res. Inst., Dept. Of Vegetable Crops And Ornamentals \\ 07100 Antalya, Turkey \\ (e-mail: filiz_boyaci@yahoo.com; phone: +90-242-724-5292; fax: +90-242-724-5293) \\ (Received $16^{\text {th }}$ Oct 2019; accepted $8^{\text {th }}$ Jan 2020)
}

\begin{abstract}
Genetic diversity in eggplant cultivars has drastically decreased due to developed varieties having similar desirable characteristics. In recent years, the breeders have taken much effort to enrich eggplant (Solanum melongena L.) genome by utilizing local populations and wild relatives similarly to the case of other plant species. In addition, wild relatives make it possible to benefit from their resistance genes which provide tolerance to biotic and abiotic stress factors. In this study, preservation and maintenance of genetic diversity by utilizing wild eggplant species to alleviate the restrictions in eggplant breeding programs caused by the limited genetic background through creating interspecific crosses was established as the main goal. In total, nine species chosen among the wild relatives of eggplant were crossed with two inbred lines developed from Solanum melongena L. Hybrid seed was available only in five crosses. Just, 38 lines developed in F4 stage from Solanum insanum. These lines were examined morphologically by using 27 descriptors. The data was analyzed by NTSYSpc: Numerical Taxonomy and Multivariate Analysis System (Version 2.0) program for understanding their phylogenetic relationship. A high variance changing in between $27 \%$ and $97 \%$ was observed among them. This result showed that they have good potentials to be used in breeding programs.
\end{abstract}

Keywords: ancestor, genetic diversity, phylogenetic relationship, relative

\section{Introduction}

Eggplant is one of the most valuable vegetables highly consumed in populated countries like India, China, Indonesia, Japan, the Philippines, in Asian countries, also in European and African countries (Frary et al., 2007; Looney, 2016). It has rich contents of minerals, antioxidants, fiber and vitamins (Kalloo, 1993; Scorsatto et al., 2017), which makes it suitable for human nutrition. Its production quantity is increasing year by year in the world. A significant part of commercialized eggplant F1 hybrid varieties have black color fruits and they are quite similar to each other (Muñoz Falcón et al., 2009). The breeder's genetic resource capacities and variants have become decreased because the gene pools used in breeding programs have been focused to develop F1 varieties that are indistinguishable from one another. Furthermore, the wide-spreading use of these commercial varieties pose a risk to the extinct of genetic diversity in a long term period (Cericola et al., 2013). Another problem faced by the breeders is that these commercial varieties are susceptible to biotic and abiotic stress factors (Rotino et al., 2014; Kacjan Maršić et al., 2014). In recent years, several studies have been launched to overcome of these problems. Eggplant's wild relatives have given opportunity to provide the enrichment of genetic diversity, improve resistance to biotic and abiotic stress factors and develop nutritional quality (Rotino et al., 2014; Syfert et al., 2016).

The studies on genetic relationship of eggplant wild relatives in genomic levels demonstrated their potential breeding values. The genetic diversity were determined among the eggplants including the usage of SSR marker systems. The close genetic relationship 
were revealed among $S$. anguvi and S. aethiopicum. Moreover S. melongena and $S$. aethiopicum showed high similarity. $S$. macrocarpon showed less genetic similarity. $S$. linnaeanum showed a close genetic relationship with $S$. aethiopicum compared with other species (Tümbilen et al., 2011). Constructed genetic map to found out phylogenetic relationship by using AFLPs markers has been revealed that Asian plants indicated one species $S$. insanum $(S$. incanum $+S$. undatum) as their ancestors. Another valuable wild relative of eggplant is $S$. incanum which is being used in eggplant breeding programmes for developing ILs against drought resistance. Also S. linnaeanum can be good resource for breeding programs regarding bacterial wilt resistance (Knapp et al., 2013). According to transcriptome analysis, the $S$. aethiopicum accession has higly intraspecific polymorphisms compared with $S$. incanum. But these African eggplants have limited potential for breeding programs in contrast to previous studies (Gramazio et al., 2016). An investigation result on gene divergence between wild and domesticated eggplants clearly showed that $S$. aethiopicum and S. integrifolium from section Oliganthes were placed in the same clade, but $S$. sisymbriifolium in the Sisymbriifolium clade was in the most distant clade from the cultivated eggplant on the generated phylogenetic tree (Wei et al., 2019).

Although eggplant has a large number and valuable of wild relatives, most of them has not been fully evaluated in breeding programs due to sexual barriers encountered during the interspecific crosses (Sihachakr et al., 1994). For example, it was declared that $S$. melongena were crossed with 19 well known relatives and fertile hybrids have been obtained only from four wild relatives' (S. incanum, S. Iinneanum, S. macrocarpon, and $S$. aethiopicum) crosses (Daunay and Lester, 1989). S. aethiopicum L. and $S$. macrocarpon L. have been the most remarkable species for the breeders (Daunay et al., 2019). Also, an inbred line successfully produced through interspecific hybridization from $S$. linneanum to ensure resistance against Verticillium wilt has been reported (Liu et al., 2015). BC and F2 progenies, having high phenolic content that are the health-beneficial compounds, obtained from hybridization of S. melongena and S. incanum have been evidence for genetic progress (Prohens et al., 2013). Despite all these successes obtained in interspecific hybridization of wild species and cultivar form of eggplant so far, the use of outputs is limited in the breeding program in practice. There is still no available commercial eggplant cultivar has been improved by using its wild relatives excepting rootstocks (Plazas et al., 2016). So there is still a need for further studies achieving gene pool having high genetic variability that can be useful for intense and public breeding programs from these precious resources.

The aim of this work is to develop more distant inbred lines in eggplant by taking advantage of its ancestors and contribute to increase genetic diversity which is the most important factor in increasing the success of breeding programs.

\section{Materials and methods}

Totally nine wild relatives and two inbred lines of Solanum melongena were used in the study. All the plant materials belonging to the wild relatives of eggplant were provided from INRA, in the Unit of Genetics and Breeding of Fruits and Vegetable, Avignon, France, by a senior researcher, Daunay, M. C. The inbred lines P45 and P5/2, having high General Combining Ability, were developed in a breeding program carried out Bati Akdeniz Agricultural Research Institute (BATEM) Antalya, Turkey. The detailed information about plant materials code, species name and origin used in the study were given in Table 1. 
Table 1. The plant materials code, species name and origin used in the study

\begin{tabular}{c|c|c}
\hline Code & Species name & Origin of materials \\
\hline MM132 & S. macrocarpon L. & INRA, France \\
MM195 & S. linnaeanum Hepper \& Jaeger & INRA, France \\
MM232 & S. aethiopicum L. Group Gilo & INRA, France \\
MM497 & S. violaceum Ort. & INRA, France \\
MM511 & S. virginianum L. & INRA, France \\
MM684 & S. incanum L. group C & INRA, France \\
MM1602 & S. viarum Dunal & INRA, France \\
MM1689 & S. anguivi Lam. & INRA, France \\
MM510 & S. insanum S. melongena L. group E) & INRA, France \\
P45 & S. melongena L. (inbred line) & BATEM, Turkey \\
P5/2 & S. melongena L. (inbred line) & BATEM, Turkey \\
\hline
\end{tabular}

The plants of study were grown under glasshouse conditions. Two inbred lines (P45 and P5/2) belonging to $S$. melongena used as females were crossed with nine wild relatives of eggplant. The fertile F1 hybrids obtained from interspecific cross were selfed to produce F2 plants. The most fertile F2 plants were selected to construct lines and F3 to F4 progenies were raised from initial P45 x S. insanum and P5/2 x S. insanum crosses. Totally 38 lines in F4 stage were generated. These lines morphology-based phylogenies were examined with 27 descriptors selected from UPOV (Union of Plant Variety), IPGRI (International Plant Genetic Research Institution) and experiences of breeder (Table 2).

Table 2. The traits, descriptors and score range used in observation for inbred lines generated from interspecific hybridization of S. melongena (P45) and S. insanum

\begin{tabular}{|c|c|}
\hline Traits & Description and Score range \\
\hline Plant habitat & $1=$ Open, $3=$ Bushy \\
\hline Plant height & $1=$ Long, $3=$ Intermediate, $5=$ Short \\
\hline Stem thickness & $1=$ Thick, $3=$ Intermediate, $5=$ Thin \\
\hline Stem hairiness & 1=Dense, $3=$ Intermediate, $5=$ Tenuous \\
\hline Stem color & 1=Grayish-green, 3=Green, 5=Green-purple 7=Purple \\
\hline Shoot tip color & 1=Grayish-green, 3=Green, 5=Green-purple 7=Purple \\
\hline Length of internodes & 1=Long, $3=$ =Intermediate, 5=Short \\
\hline Leaf color & $1=$ Green, $3=$ Light green, $5=$ Dark green \\
\hline Leaf size & $1=$ Large, $3=$ Intermediate, $5=$ Small \\
\hline Leaf hairiness & $1=$ Dense, $3=$ Intermediate, $5=$ Tenuous \\
\hline Presence of spine on petiole & 1=Many, $3=$ Intermediate, $5=$ Few, $7=$ Absent \\
\hline Bud size & 1=Large, $3=$ Intermediate, $5=$ Small \\
\hline Bud hairiness & $1=$ Dense, $3=$ Intermediate, $5=$ Tenuous, $7=$ Absent \\
\hline Presence of spine on bud & $1=$ Many, $3=$ Intermediate, $5=$ Few, $7=$ Absent \\
\hline Flower color & 1=Light purple, 3=Purple, 5=Dark purple, $7=$ White \\
\hline Flower size & 1=Large, $3=$ Intermediate, $5=$ Small \\
\hline Fruit shape & 1=Long, $3=$ Intermediate, $5=$ Short, $7=$ Ovoid, $9=$ Pear shaped \\
\hline Fruit color & 1=Light purple, $3=$ =Purple, $5=$ Green \\
\hline Fruit length $(\mathrm{cm})$ & $1=2-3,3=4-5,5=6-7,7=8-9$ \\
\hline Fruit diameter $(\mathrm{cm})$ & $1=5-7,3=8-10,5=11-13,7=14-16$ \\
\hline Average fruit weight $(\mathrm{g})$ & $1=9-34,3=35-60,5=61-86,7=87-112,9=113-138,11=139-164$ \\
\hline Fruit flesh color & $1=$ Greenish-cream, $3=$ Green, $5=$ White \\
\hline Fruit end shape & $1=$ Round, $3=$ Pointed, $5=$ Flat \\
\hline Fruit groove & $1=$ Present, $3=$ Absent \\
\hline Calyx size & $1=$ Large, $3=$ Intermediate, $5=$ Small \\
\hline Presence of seed in fruit & $1=$ Absent, $3=$ One or two, $5=$ Few, $7=$ Intermediate, $9=$ Many \\
\hline Seed mature & 1=Absent, $3=$ Immature, 5=Mature, $7=$ Imbibed mature seeds \\
\hline
\end{tabular}


Descriptions and score range were modified from UPOV and IPGRI eggplant descriptors. The characteristics were scored according to and compared with recognized cultivar S. melongena cv. Long Purple. All observations determined by measurement or counting were made on 10 plants or parts taken from each of 10 plants. Numerical data regarding fruit characteristics for each line were collected from ten harvested fruits.

The relationship among inbred lines was investigated by the technique of UPGMA, the clustering procedure was carried out using NTSYS-PC version 2.2 (Rohlf, 1998). Through the utilization of clustering technique UPGMA via SHAN module, the dendrograms were created. The cophenetic correlation coefficient was determined with the Mantel technique so as to assess the clustering effectiveness.

\section{Results and discussion}

The F1 hybrids from some interspecific crosses between the inbred lines and wild species were produced to create novel diversity that is peculiar to wild species. Only five interspecific hybrids were attained from crosses between P45 which is a parental line and $S$. macrocarpon, $S$. linnaeanum, $S$. aethiopicum, $S$. incanum and $S$. incanum among the nine species were tested in the study. Also, P5/2 produced just four hybrids from S. macrocarpon, S. linnaeanum, S. incanum and S. incanum crosses. However, interspecific F1 hybrid of $S$. aethiopicum was unfertile. The interspecific hybridization between inbred lines and $S$. violaceum, $S$. virginianum and $S$. anguvi were unsuccessful (Table 3). Some hybrids and their parents obtained from S. melongena (P45) $\mathrm{x}$ $S$. incanum, S. melongena (P45) x S. macrocarpon, S. melongena (P45) x S. insanum, S. melongena $(\mathrm{P} 5 / 2) \times \mathrm{S}$. insanum crossing are shown in Fig. 1.

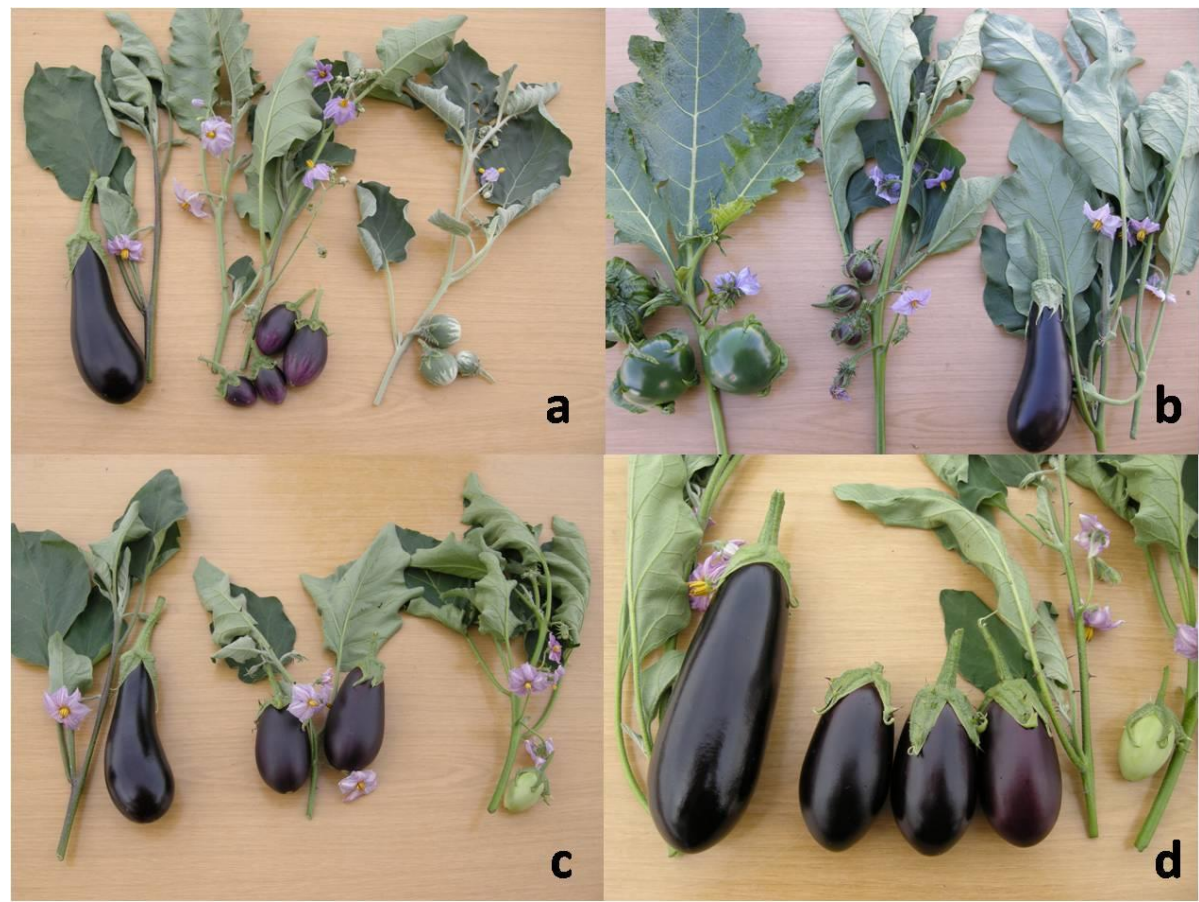

Figure 1. Some hybrids and their parents obtained from crosses of S. melongena (P45) x S. incanum (a), S. melongena (P45) x S. macrocarpon (b), S. melongena (P45) x S. insanum (c), $S$. melongena $(P 5 / 2) \times S$. insanum $(d)$ 
Table 3. The results of interspecific crosses between two inbred lines belonging to the S. melongena and nine wild relatives of eggplant

\begin{tabular}{|c|c|c|c|c|c|c|c|c|c|c|}
\hline $\mathbf{X}$ & $\begin{array}{c}S . \\
\text { macrocarpon }\end{array}$ & $\begin{array}{c}S . \\
\text { linnaeanum } \\
\end{array}$ & $\begin{array}{c}S . \\
\text { aethiopicum } \\
\end{array}$ & $\begin{array}{c}S . \\
\text { violaceum }\end{array}$ & $\begin{array}{c}S . \\
\text { insanum }\end{array}$ & $\begin{array}{c}S . \\
\text { virginianum } \\
\end{array}$ & $\begin{array}{c}S . \\
\text { incanum }\end{array}$ & $\begin{array}{c}S . \\
\text { anguvi }\end{array}$ & $\begin{array}{c}\text { S. melongena } \\
(\mathbf{P 4 5})\end{array}$ & $\begin{array}{c}\text { S. melongena } \\
(\mathrm{P} 5 / 2)\end{array}$ \\
\hline $\begin{array}{c}S . \\
\text { macrocarpon }\end{array}$ & $+^{*}$ & & & & & & & & & \\
\hline S. linnaeanum & & + & & & & & & & & \\
\hline S. aethiopicum & & & + & & & & & & & \\
\hline S. violaceum & & & & + & & & & & & \\
\hline S. insanum & & & & & + & & & & & \\
\hline S. virginianum & & & & & & - & & & & \\
\hline S. incanum & & & & & & & + & & & \\
\hline S. anguvi & & & & & & & & - & & \\
\hline $\begin{array}{l}\text { S. melongena } \\
(\mathbf{P 4 5})\end{array}$ & + & + & + & - & + & - & + & - & + & + \\
\hline $\begin{array}{c}\text { S. melongena } \\
(\mathrm{P} 5 / 2)\end{array}$ & + & + & $-* *$ & - & + & - & + & - & + & + \\
\hline
\end{tabular}

*: Successful crosses, F1 hybrids were obtained (+), **: Unsuccessful crosses, F1 hybrid were not obtained because of sexual barriers (-) 
The production of F2 generation plants were realized by hand pollination of F1 plants obtained from only three crosses performed among P45 and three wild relatives (S. macrocarpon, $S$. incanum and $S$. insanum) and $\mathrm{P} 5 / 2 \times \mathrm{x}$. insanum. Only, the progenies derived from inbred lines ( $\mathrm{P} 45$ and $\mathrm{P} 5 / 2$ ) and $S$. insanum crosses were appropriated to sustain of F4 generations having desirable morphologic characters. 38 inbred lines in F4 stage were produced from YAB3-YAB15: P45 x $S$. insanum, YAB7-YAB16: P5/2 x $S$. insanum crosses. The other progenies generated from $S$. macrocarpon and $S$. incanum showed inconvenient characteristic specials sourced from recombination. And they were not sustainable for breeding studies. These findings were consistent with some results presented in previous studies, but not with the others. Schaff et al. (1982) reported that the fertile F1 and F2 plants have been produced from $S$. melongena $\mathrm{x}$. macrocarpon crosses where as the F1 hybrids could be obtained after embryo rescue from $S$. melongena x $S$. aethiopicum and $S$. melongena x $S$. insanum. $S$. melongena x $S$. gilo produced only sterile F1 hybrids. Also, the producing fertile hybrid from $S$. macrocarpon was notified by Kashyap (2002). In another study, Bletsos et al. (2004) obtained success from one cross among three crosses of S. melongena and $S$. macrocarpon. They stated that the female genotype plays a major effect on the success of interspecific cross. Similarly, we detected maternal effect in our study. For example, although $\mathrm{P} 45$ produced $\mathrm{F} 1$ hybrid in hybridization with $S$. aethiopicum but P5/2 did not show good performance in hybridization. This means that crossability of P45 with wild relatives can be sourced from its ancestor genes in the background. Additionally, F1 hybrids produced from crosses P5/2 and two wild relatives of eggplant (S. macrocarpon, S. incanum) had ungerminated seeds. In other study, Gowda et al. (1990) claimed contrarily that the interspecific cross of $S$. macrocarpon produce sterile hybrids due to the ovule abortion. It has been reported by Schaff et al. (1982) that the subsequent progenies were limited due to the recombination effect observed in the formation of F2 produced from $S$. macrocarpon hybrids. Taher et al. (2017) also mentioned translocation formation during meiosis in plants. Davidar et al. (2015) found out that the interspecific cross between $S$. insanum and eggplant cultivars by hand pollination had low fruit set. However, Prohens et al. (2013) informed that the highly valuable BC1P2 plants have been developed from $S$. incanum for phenolic compound improvement of functional quality. In another study, a new wild genepool consructed from interspecific cross of $S$. melongena and S. elaeagnifolium. This genepool carries to $\mathrm{BC} 1$ generation had intermediate attribute according to their parents and it is quite valuable for eggplant breeding, as it was reported by García-Fortea et al. (2019). Furthermore, Kouassi et al. (2016) have made interspecific cross between six eggplant varieties and 10 accessions of wild relatives. They obtained 44 interspecific hybrids $S$. insanum, S. anguivi, S. dasyphyllum, S. incanum, S. lichtensteinii, and S. tomentosum. The first backcross generations from crosses with hybrids between $S$. melongena and $S$. insanum had been achieved. Identically, the most efficient wild relative of eggplant was $S$. insanum in our study.

Using morphologic descriptors, the phylogenetic relationships among 38 inbred lines were revealed. While 24 of the 27 criteria used revealed the morphological differences among the inbred lines, 3 criteria regarding stem, shoot tip and leaf color did not affect the separation of the lines. The eigenvalue was $92 \%$ for 5 determinants. Mantel t-test values were approximately $\mathrm{t}=6.5842, \mathrm{p}=1.0000$ for the 2 -way technique of Mantel Test (Mantel, 1967). Matrix correlation (r) was 0.87 (as normalized Mantel Z-Statistic) and this value was in acceptable levels. The $r$ value verified a significant relationship 
between genetic distance matrices. The graph created from comparison of similarity matrices contains points indicating high correlation (Fig. 2).

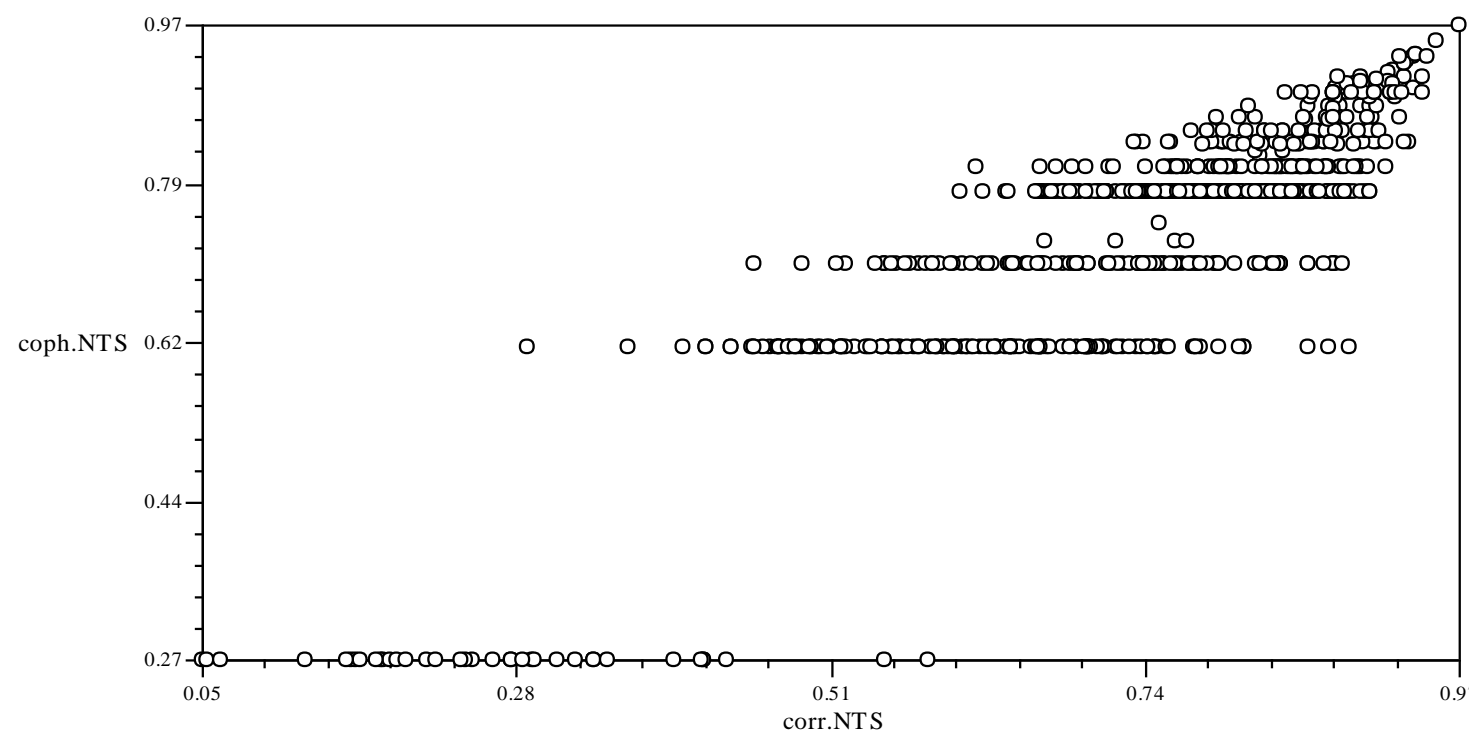

Figure 2. The correlation between the genetic distance matrices constructed from morphological data of F4 inbred lines improved from interspecific cross between S. melongena and S. insanum using Mantel tests

The dendrogram was formed with matrices of distance by following the unweighted pair group technique with arithmetic means (UPGMA) for phylogenetic examination (Fig. 3). The rates of similarity in accordance with inbred lines' coefficient similarity varied between 0.27 and 0.97. Following the UPGMA method, the lines in F4 stage generated from interspecific crosses were divided into 2 primary groups. One inbred line formed the first group (A). This line was considerably distinct compared to all other inbred line genotypes. 37 inbred lines as a majority formed the second group (B) and they were once again divided into 2 different subgroups. The first subgroup (C) consisted of four inbred lines that were developed from $\mathrm{P} 45 \times \mathrm{S}$. insanum. The greatest similarity was discovered in the $2^{\text {nd }}$ subgroup (D). The inbred lines of YAB 16/9-3 and YAB 16/9-4 which belonged to the 2nd subgroup demonstrated high genetic similarity with 97\% similarity rate. Although, YAB3/1-4 and YAB3/1-6 were developed from same the crosses, they had the furthest genetic distance (27\% similarity rate). It was observed in the dendrogram that the lines developed from both sources were dispersed scatter inside each other. The lines which were developed from both sources did not show a significant distribution amongst themselves. The appearance regarding fruit characteristics of some lines in F4 stage are given in Figure 4.

Similarity rates in other studies related to intercrosses of eggplant wild relatives are as follows. Kaushik et al. (2018) evaluated 45 hybrids that were generated from inbred $S$. melongena and $S$. insanum intercrosses by using 14 morphological and agronomic descriptors. A broad range of genetic diversity among these genotypes was also founded by them. S. melongena consisting eighty-eight accessions, and four wild relatives (S. insanum, S. incanum, S. integrifolium and S. sysimbriifolium) have been examined to determine genetic similarity by using molecular markers. The lowest and highest similarity rate was found to be as 0.47 and 0.67, respectively (Behera et al., 2006). 
Likewise, Karihaloo et al. detected in both molecular (1995a) and enzyme electrophoretic (1995b) studies that the similarity rate of $S$. melongena and S. insanum is more than $91 \%$. In contrast, the similarity rate changed in between 0.27 and 0.97 in our findings and the genetic diversity had considerably high values.

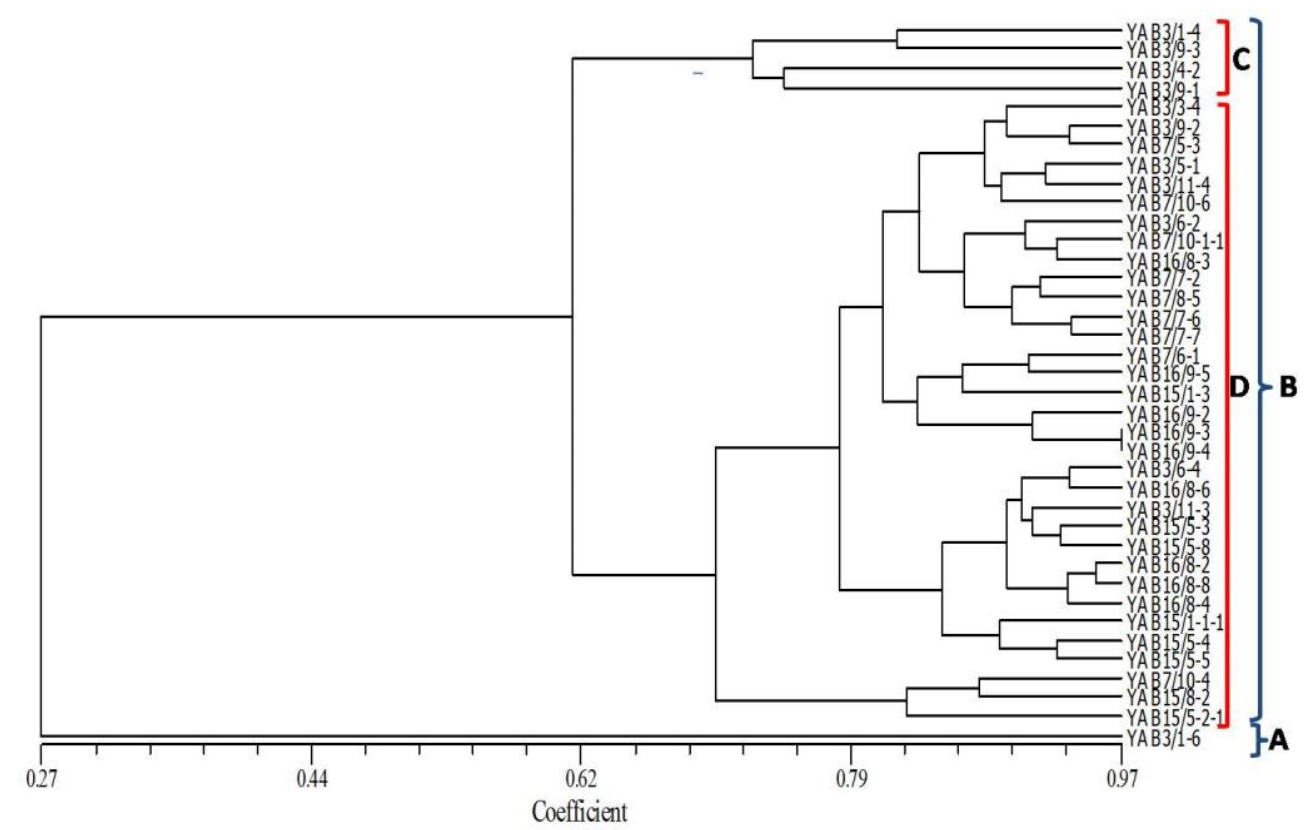

Figure 3. Dendrogram generated based morphological data of 38 inbred lines (YAB3-YAB15: P45 $x$ S. insanum, YAB7-YAB16: P5/2 $x$ S. insanum) using the Underweighted Pair-Group Method with Arithmetic Mean cluster analysis of DICE (1945) genetic similarity coefficients

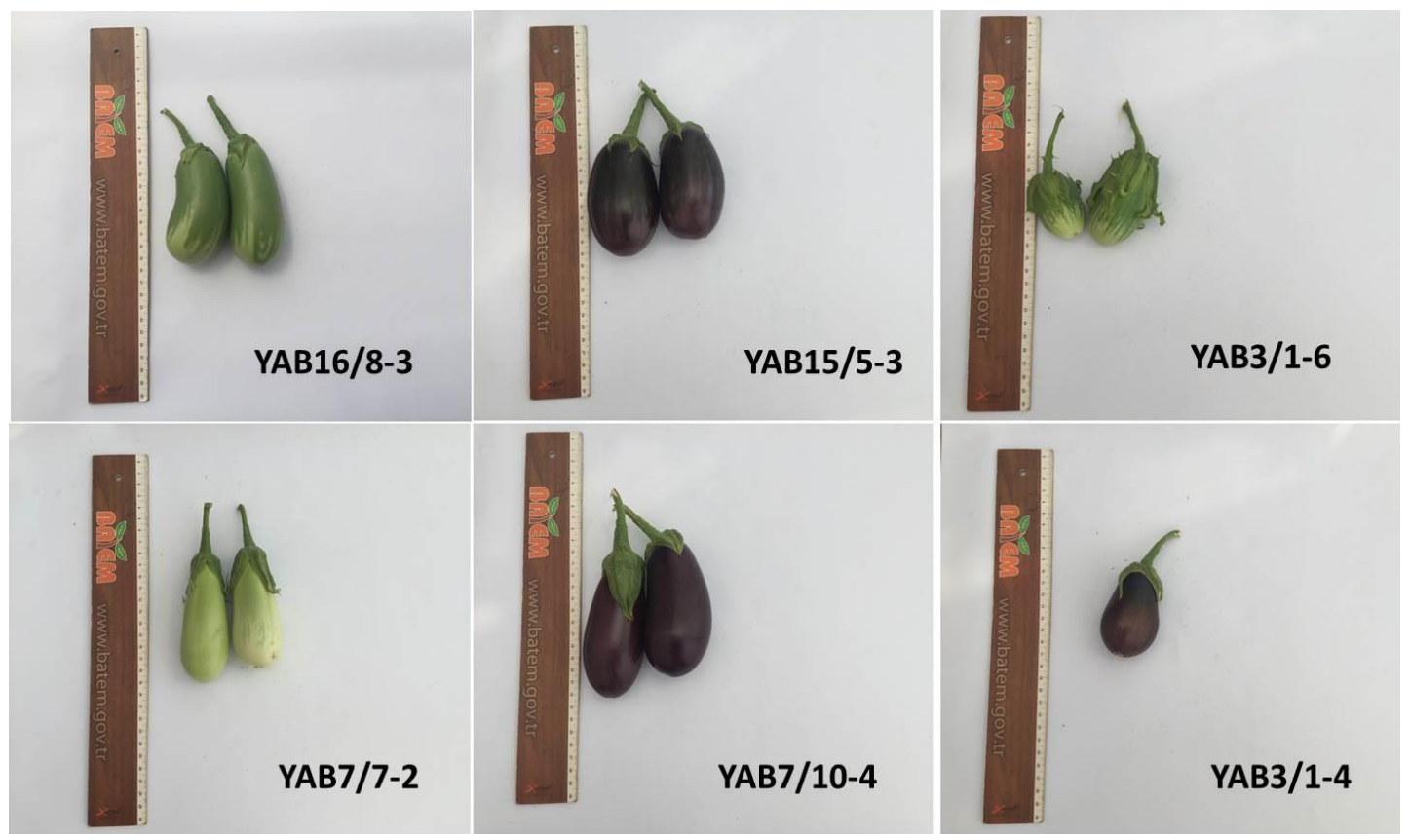

Figure 4. The appearance regarding fruit characteristics of some lines (YAB3-YAB15:P45 $x$ S. insanum, YAB7-YAB16: P5/2 $\times$ S. insanum) in F4 stage 
It was specified by Kaushik (2019) that $S$. insanum which was used as a tester for observing specific combining ability (SCA) and general combining ability (GCA) components effects and heterosis rates was a better tester for important morphological features. Although Solanum insanum L., natural plant of Asia and Africa, carried great potential for breeding studies, it has not paid enough attention by the breeders. Because of having great potential to cross with eggplant cultivar forms, more effort is needed to use it in breeding programs (Ranil et al., 2017).

\section{Conclusion}

This study yielded a first report related on genetic diversity of inbred lines developed in interspecific hybridization. Solanum insanum, ancestor of Solanum melongena, was identified as a good source for emerging survival next generations of inbred lines. It was defined that these lines carried F4 stage had a wide diversity in point of morphologic characters, carried biotic/abiotic stress resistance and being a good source for improving new eggplant variety that shows multiple resistance against some important stress factors. Since the success of these interspecific hybridization programs are highly dependent upon the parents used, a serious effort should be required on new interspecific crosses by using different female parents.

In conclusion, eggplant successful hybridized with $S$. insanum. Integrossion of ancestor genes to the cultivar form provided increase of genetic diversity. The developed lines from the $S$. insanum can contribute to develop commecial variety because they have the desired features like purple-colored fruit, without prickles plants etc. Our results may be relevant for the breeders and contibute to the enhancement of eggplant gene pool.

Acknowledgements. This research was financially supported by grants from the General Directorate of Agricultural Research and Policy, Republic of Turkey Ministry of Agriculture and Forestry under TAGEM/BBAD/10/A09/P01/12 project number.

\section{REFERENCES}

[1] Behera, T. K., Sharma, P., Singh, B. K., Kumar, G., Kumar, R., Mohapatra, T., Singh, N. K. (2006): Assessment of genetic diversity and species relationships in eggplant (Solanum melongena L.) using STMS markers. - Scientia Horticulturae 107(4): 352-357.

[2] Bletsos, F., Roupakias, D., Tsaktsira, M., Scaltsoyjannes, A. (2004): Production and characterization of interspecific hybrids between three eggplant (Solanum melongena L.) cultivars and Solanum macrocarpon L. - Scientia Horticulturae 101(1-2): 11-21.

[3] Cericola, F., Portis, E., Toppino, L., Barchi, L., Acciarri, N., Ciriaci, T., Sala, T., Rotino, G. L., Lanteri, S. (2013): The population structure and diversity of eggplant from Asia and the Mediterranean Basin. - PloS one 8(9): e73702.

[4] Daunay, M. C., Lester, R. N. (1989): The usefulness of taxonomy for Solanaceae breeders, with special reference to the genus Solanum and to Solanum melongena L. (eggplant). - Capsicum Newslett 7: 10.

[5] Daunay, M.-C., Salinier, J., Aubriot, X. (2019): Crossability and Diversity of Eggplants and Their Wild Relatives. - In: Chapman, M. (ed.) The Eggplant Genome: 135-191.

[6] Davidar, P., Snow, A. A., Rajkumar, M., Pasquet, R., Daunay, M. C., Mutegi, E. (2015): The potential for crop to wild hybridization in eggplant (Solanum melongena; Solanaceae) in southern India. - American Journal of Botany 102(1): 129-139. 
[7] Frary, A., Doganlar, S., Daunay, M. C. (2007): Eggplant. - In: Kole C. (ed.) Genome Mapping and Molecular Breeding in Plants, Vol. 5: Vegetables: 287-313. Berlin: Springer. doi: 10.1007/978-3-540-34536-7_9.

[8] García-Fortea, E., Gramazio, P., Vilanova, S., Fita, A., Mangino, G., Villanueva, G., Arrones, A., Knapp, S., Prohens, J., Plazas, M. (2019): First successful backcrossing towards eggplant (Solanum melongena) of a New World species, the silverleaf nightshade (S. elaeagnifolium), and characterization of interspecific hybrids and backcrosses. Scientia Horticulturae 246: 563-573.

[9] Gowda, P. H. R., Shivashankar, K. T., Joshi, S. H. (1990): Interspecific hybridization between Solanum melongena and Solanum macrocarpon: study of the F1 hybrid plants. Euphytica 48(1): 59-61.

[10] Gramazio, P., Blanca, J., Ziarsolo, P., Herraiz, F. J., Plazas, M., Prohens, J., Vilanova, S. (2016): Transcriptome analysis and molecular marker discovery in Solanum incanum and $\mathrm{S}$. aethiopicum, two close relatives of the common eggplant (Solanum melongena) with interest for breeding. - BMC genomics 17(1): 300.

[11] Kacjan Maršić, N., Mikulič-Petkovšek, M., Štampar, F. (2014): Grafting influences phenolic profile and carpometric traits of fruits of greenhouse-grown eggplant (Solanum melongena L.). - Journal of Agricultural and Food Chemistry 62(43): 10504-10514.

[12] Kalloo, G. (1993): Eggplant: Solanum melongena L. - In: Genetic improvement of vegetable crops: 587-604. Pergamon.

[13] Karihaloo, J. L., Brauner, S., Gottlieb, L. D. (1995a): Random amplified polymorphic DNA variation in the eggplant, Solanum melongena L. (Solanaceae). - Theoretical and Applied Genetics 90(6): 767-770.

[14] Karihaloo, J. L., Gottlieb, L. D. (1995b): Allozyme variation in the eggplant, Solanum melongena L. (Solanaceae). - Theoretical and Applied Genetics 90(3-4): 578-583.

[15] Kashyap, V., Kumar, S. V., Collonnier, C., Fusari, F., Haicour, R., Rotino, G. L., Sihachakr, D., Rajam, M. V. (2003): Biotechnology of eggplant. - Scientia Horticulturae 97(1): 1-25.

[16] Kaushik, P., Plazas, M., Prohens, J., Vilanova, S., Gramazio, P. (2018): Diallel genetic analysis for multiple traits in eggplant and assessment of genetic distances for predicting hybrids performance. - PloS one 13(6): e0199943.

[17] Kaushik, P. (2019): Line $\times$ Tester Analysis for Morphological and Fruit Biochemical Traits in Eggplant (Solanum melongena L.) Using Wild Relatives as Testers. - Agronomy 9(4): 185.

[18] Knapp, S., Vorontsova, M. S., Prohens, J. (2013): Wild relatives of the eggplant (Solanum melongena L.: Solanaceae): new understanding of species names in a complex group. - PloS one 8(2): e57039.

[19] Kouassi, B., Prohens, J., Gramazio, P., Kouassi, A. B., Vilanova, S., Galán-Ávila, A., Herraiz, F. J., Kouassi, A., Seguí-Simarro, J. M., Plazas, M. (2016): Development of backcross generations and new interspecific hybrid combinations for introgression breeding in eggplant (Solanum melongena). - Scientia Horticulturae 213: 199-207.

[20] Liu, J., Zheng, Z., Zhou, X., Feng, C., Zhuang, Y. (2015): Improving the resistance of eggplant (Solanum melongena) to Verticillium wilt using wild species Solanum linnaeanum. - Euphytica 201(3): 463-469.

[21] Looney, N. E. (2016): Fruits, vegetables and tubers: bountiful resources for achieving and sustaining food and nutrition security. - In: Pritchard, B., Ortiz, R., Shekar, M. (eds.) Routledge Handbook of Food and Nutrition Security: 38-58. Routledge, New York.

[22] Mantel, N. (1967): Assumption-free Estimators Using U Statistics and a Relationship to the Jackknife Method. - Biometrics 23(3): 567-571.

[23] Muñoz Falcón, J. E., Prohens, J., Vilanova, S., Nuez, F. (2009): Diversity in commercial varieties and landraces of black eggplants and implications for broadening the breeders' gene pool. - Annals of Applied Biology 154(3): 453-465. 
[24] Plazas, M., Vilanova, S., Gramazio, P., Rodríguez-Burruezo, A., Fita, A., Herraiz, F. J., Ranil, R., Fonseka, R. M., Niran, L., Fonseka, H., Kouassi, B., Kouassi, A. B., Kouassi, A., Prohens, J. (2016): Interspecific hybridization between eggplant and wild relatives from different genepools. - Journal of the American Society for Horticultural Science 141(1): 34-44.

[25] Prohens, J., Whitaker, B. D., Plazas, M., Vilanova, S., Hurtado, M., Blasco, M., Gramazio, P., Stommel, J. R. (2013): Genetic diversity in morphological characters and phenolic acids content resulting from an interspecific cross between eggplant, Solanum melongena, and its wild ancestor (S. incanum). - Annals of Applied Biology 162(2): 242257.

[26] Ranil, R. H. G., Prohens, J., Aubriot, X., Niran, H. M. L., Plazas, M., Fonseka, R. M., Vilanova, S., Fonseka, H. H., Gramazio, P., Knapp, S. (2017): Solanum insanum L. (subgenus Leptostemonum Bitter, Solanaceae), the neglected wild progenitor of eggplant (S. melongena L.): a review of taxonomy, characteristics and uses aimed at its enhancement for improved eggplant breeding. - Genetic resources and crop evolution 64(7): 1707-1722.

[27] Rohlf, F. J. (1998): NTSYS-PC: Numerical taxonomy and multivariate analysis system. Release 2.20j. - Exeter Software, Setauket, NY.

[28] Rotino, G. L., Sala, T., Toppino, L. (2014): Eggplant. - In: Pratap, A., Kumar, J. (eds.) Alien Gene Transfer in Crop Plants, Vol. 2: 381-409. Springer, New York, NY.

[29] Schaff, D. A., Jelenkovic, G., Boyer, C. D., Pollack, B. L. (1982): Hybridization and fertility of hybrid derivatives of Solatium melongena L. and Solanum macrocarpon L. Theoretical and Applied Genetics 62(2): 149-153.

[30] Scorsatto, M., Rosa, G., Raggio Luiz, R., da Rocha Pinheiro Mulder, A., Junger Teodoro, A., Moraes de Oliveira, G. M. (2019): Effect of Eggplant Flour (Solanum melongena L.) associated with hypoenergetic diet on antioxidant status in overweight women-a randomised clinical trial. - International Journal of Food Science \& Technology 54(6): 2182-2189.

[31] Sihachakr, D., Daunay, M. C., Serraf, I., Chaput, M. H., Mussio, I., Haicour, R., Rossignol, L., Ducreux, G. (1994): Somatic hybridization of eggplant (Solanum melongena L.) with its close and wild relatives. - In: Bajaj, Y. P. S. (ed.) Biotechnology in Agriculture Forestry 27, Somatic Hybridization in Crop Improvement I: 255-278. Springer, Berlin, Heidelberg.

[32] Syfert, M. M., Castañeda-Álvarez, N. P., Khoury, C. K., Särkinen, T., Sosa, C. C., Achicanoy, H. A., Bernau, V., Prohens, J., Daunay, M. C., Knapp, S. (2016): Crop wild relatives of the brinjal eggplant (Solanum melongena): poorly represented in genebanks and many species at risk of extinction. - American journal of botany 103(4): 635-651.

[33] Taher, D., Solberg, S. Ø., Prohens, J., Chou, Y. Y., Rakha, M., Wu, T. H. (2017): World Vegetable Center Eggplant Collection: Origin, Composition, Seed Dissemination and Utilization in Breeding. - Frontiers in plant science 8: 1484.

[34] Tümbilen, Y., Frary, A., Daunay, M. C., Doğanlar, S. (2011): Application of EST-SSRs to examine genetic diversity in eggplant and its close relatives. - Turkish Journal of Biology 35(2): 125-136.

[35] Wei, Q., Du, L., Wang, W., Hu, T., Hu, H., Wang, J., David, K., Bao, C. (2019): Comparative Transcriptome Analysis in Eggplant Reveals Selection Trends during Eggplant Domestication. - International journal of genomics, Vol. 2019. 